\title{
VIVAT - Førstehjelp ved selvmordsfare
}

Ved Kirsti Silvola

Vinteren 2000 ble det landsdekkende undervisningsprosjektet VIVAT opprettet som ett av flere oppfølgingsprosjekter til Handlingsplan mot selumord. VIVAT betyr "la henne/ham leve", og har som mål å spre kunnskap om førstehjelp ved selumordsfare

U ndervisningsprosjektet har sitt utspring i et kursprogram som er utviklet av organisasjonen LivingW orks Education i Calgary, Canada, og som er brukt i over 15 år i mange land.

Senter for forebygging av selvmord $i$ N ord-N orge har siden 1998 brukt kursprogrammet fra $\mathrm{C}$ anada. D ette har fungert godt i N ord-N orge, og Staten s hel setilsyn ønsket derfor à gi samme tilbud til hele landet. A gen da U tredning og U tvikling A S, som har evaluert $H$ andlingsplan mot selvmord, anbefaler videreføring av kursopplegget og setter spesielt søkelys på den gode pedagogiske oppbyggingen av kurset, kostnadseffektiv kompetanseoppbygging, standardisert innhold og god spredningseffekt.

\section{Mål}

H ovedmålet for VIVAT er å gi fagpersoner med ulik bakgrunn kunnskaper og ferdigheter slik at de bedre kan hjelpe mennesker i akutte selvmordskriser. 0 pplegget består av to tverrfaglige kurs. Selve "produktet" er kurset "Førstehjelp ved selvmordsfare". På et eget kurslederkurs utdanner man fagfolk med ulik bakgrunn til å bli kursledere for dette førstehjelpskurset.

\section{Kurset "Førstehjelp ved selvmordsfare"}

Kurset, som tidligere ble kalt

"Intervensjon ved selvmordsfare", ble første gang gjennomført i N ord-N orge vinteren 1998. Siden da har mer enn 2000 personer deltatt.

"Førstehjelp ved selvmordsfare" er et intensivt kurs over to dager (14 timer) med to kursledere og maksimalt 24 deltakere. Det retter seg mot alle som i sitt virke møter selvmordsnære mennesker. Det er et praktisk, tverrfagl ig kurs hvor deltakerne lærer å tolke faresignaler og gripe inn ved akutt selvmordsfare. A ktuelle deltakergrupper er helsearbeidere, sosialarbeidere, kirkelige ansatte, politifolk, ambulansepersonell, frivillige hjelpere, personalansvarlige osv. Kurset gjennomføres ved forelesninger, videofilmer, diskusjoner og praktiske øvelser. H vert kurs blir evaluert av deltakerne og kurslederne.

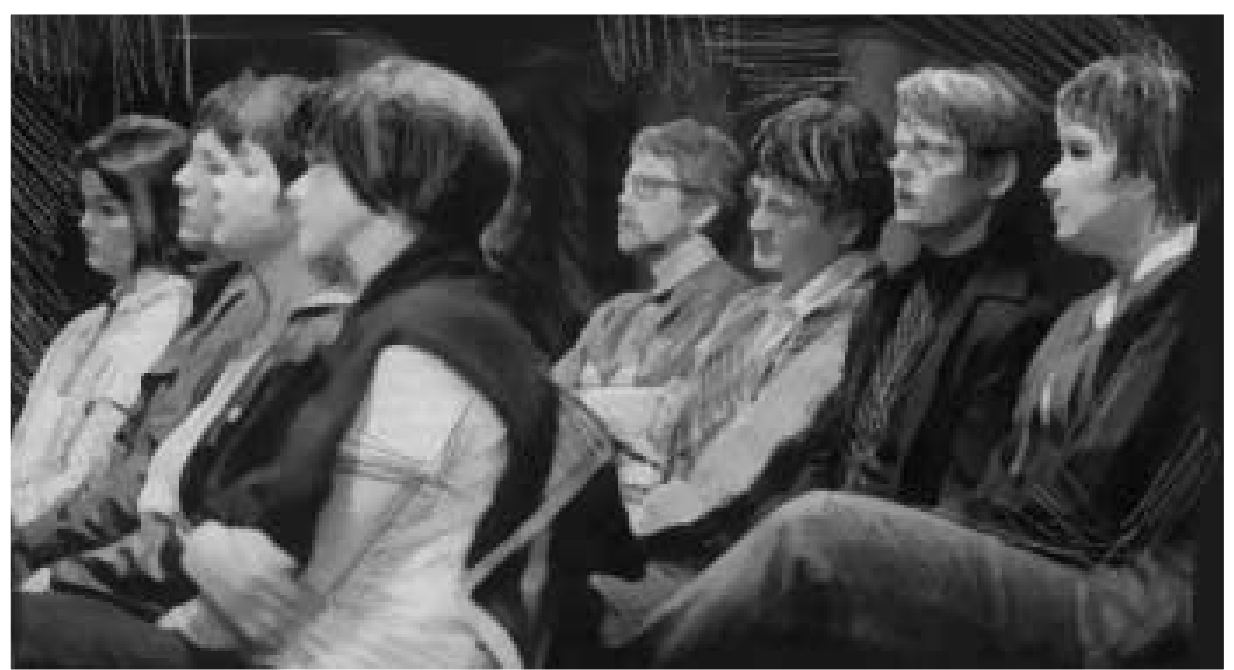

\section{Kurslederkurset}

Kurslederkurset er et intensivt femdagers kurs for utdanning av fremtidige kursledere med ulik yrkesbakgrunn. Kurslederkurset krever aktiv deltakelse, da det for en stor del arbeides i smågrupper med realistisk undervisningstrening. G odkjent kursleder er man først når man har undervist i kurset "Førstehjelp ved selvmordsfare" tre ganger i løpet av det første året etter gjennomgåatt kurslederkurs, og deretter minst en gang årlig. Kursledere må ha praktisk erfaring i selvmordsforebygging, være personlig egnet og ha pedagogiske evner til å undervise og lede smågrupper.

$\mathrm{H}$ ittil har mer enn 70 fagpersoner deltatt i kurslederopplæring. Kursledere kommer fra forskjellige arbeidsplasser, som f. eks. kommuner, Forsvaret, Kirken, politi, barne- og ungdomspsykiatri, distriktspsykiatriske sentra, skoleverket med bl.a. høyskoler osv. Det finnes gode og spennende erfaringer om samarbeid melIom to eller flere kursledere med forskjellig bakgrunn. Det er en krevende oppgave å bli kursleder, men rollen oppleves inspirerende og given de, og kompetansen oppleves verdifull.

For å kunne bruke sin kurslederkompetanse er det viktig med støtte fra arbeidsgiver.

VIVAT utdanner også erfarne kursledere til regional e veiledere, som støtter lokale kursledere i praktiske og faglige spørsmål. Veiledere fungerer også som lærerstab ved kurslederkurs.

\section{Lokalisering og arbeidsoppgaver}

VIVAT er lokalisert ved Senter for forebygging av selvmord i $\mathrm{N}$ ord-N orge, Psykiatrisk avdeling, R egion sykehuset i Tromsø. Prosjektets styringsgruppe består av fire medlemmer med professor Lars M ehlum som leder. Psykiater Kirsti Silvola arbeider som prosjektleder i $50 \%$ stilling og sekretær H arriet Johansen i 50 \% stilling.

VIVAT skal utdanne lokale kursledere og regionale veiledere, bygge og understøtte kursledernettverket og videreutvikle og kvalitetssikre kurset "Førstehjelp ved selvmordsfare". VIVAT samarbeider med Seksjon for selvmordsforskning og forebygging og med LivingW orks Education i C al gary. En stor utfordring for V IVAT er å gjøre ferdig "fornorsking" av kursmaterial et. M esteparten av dette regner vi med å ha gjort i løpet av år 2000.

\section{Neste kurslederkurs}

Det arrangeres to kurslederkurs i hvert prosjektår. D et neste skal være 5. - 9. februar 2001 på Eidene senter ved T jøme i Vestfold. De som er interesserte, kan kontakte V IVAT for å få mer informasjon om søknadsprosess og praktiske detaljer, tlf. 776 27819, e-post: vivat@rito.no Informasjon fins også på Internett: $h t t p: / / w w w$.

med.uio.no/ipsy/ssff/kurslederkurs.htm

K irsti Silvola er psykiater og leder for Senter for forebygging av selvmord i N ord-N orge. 